\title{
Supply Chain Management and Retailing
}

Leigh Sparks

Professor of Retail Studies, Institute for Retail Studies, Stirling Management School University of Stirling, UK Leigh.Sparks@stir.ac.uk

Retailers are now the dominant partners in most supply systems and have used their positions to re-engineer operations and partnerships with suppliers and other logistic service providers. No longer are retailers the passive recipients of manufacturer allocations, but instead are the active channel controllers organizing supply in anticipation of, and reaction to consumer demand. This paper reflects on the ongoing transformation of retail supply chains and logistics. If considers this transformation through an examination of the fashion, grocery and selected other retail supply chains, drawing on practical illustrations. Current and future challenges are then discussed.

Keywords : Retailing, Supply Chain Management, Supply Chain transformation, fashion Supply Chain, Grocery Supply Chain.

\section{Introduction}

Retailers were once the passive recipients of products allocated to stores by manufacturers in the hope of purchase by consumers and replenished only at the whim and timing of the manufacturer. Today, retailers are the controllers of product supply in anticipation of, and reaction to, researched, understood, and real-time customer demand. Retailers now control, organise, and manage the supply chain from production to consumption. This is the essence of the retail logistics and supply chain transformation that has taken place since the latter part of the twentieth century.

Retailers have become the channel captains and set the pace in logistics. Having extended their channel control and focused on corporate efficiency and effectiveness, retailers have then attempted to engender a more integrated, cooperative, and collaborative position in many aspects of logistics and supply chain management. They recognise that there are still gains to be made on standards and efficiency but that these are probably mostly obtained as channel or supply chain gains (i.e., in association with manufacturers, suppliers, logistics services providers, and consumers) rather than at the retailer level. The overall focus for retailers has thus moved from an emphasis on the functional aspects of receiving products to an integrative approach that develops and manages end-to-end supply chains.

Figure 1 summarises this transformation from the perspective of a senior director of Aurora Fashions (Coast, Oasis, Karen Millen, Warehouse). Roberts (2010) points to the changing capability, technology, and expectations of retail supply chains and the extension of these demands on those involved in satisfying retail needs. At one level the requirements remain the same (product availability is fundamental) but the ways of achieving this effectively and efficiently have been transformed.

This brief article explores this transformation at the macro level (see also Fernie, 1997; Sparks, 1998) and also considers the challenges that remain for retailers and their 


\section{Overview of the historical position (1970s/early 1980s)}

- 'Warehousing and transport', not 'logistics and supply chain'

- A job, not a career or profession

- Local and regional distribution centres (DCs), multiple inventories, UK only

- Simple staffing structures, quite easy to manage

- Few direct imports, either UK sourced or landed stock

- Distribution reactive not proactive, tail end Charlie, usually got the blame

- No IT systems, telephone ordering, paper-based orders, and picking

- Easy to put on extra staff at times of need

- Activity and performance measurement not prominent

- One basic channel to market: DC to store or distributor

- Less traffic congestion, few delivery restrictions, timed deliveries not needed

- Trunking and outbases not a big feature

\section{Where we are today}

- Centralised UK/European DCs or composite regional sites

- Highly complex, managerially demanding and totally systems-dependent

- Complex and far-reaching trunking and delivery patterns

- Multiple outbases, international schedules, frequent and time-critical DC cut-offs

- Multiple channels to market, all with own particular dynamics

- Logistics and supply chain an integral part of the business process

- Much more competitive retail environment, profits harder to achieve

- Inevitable cost pressures and the need to sweat assets and inventory ever harder

- Longer supply chains, most goods imported, inbound delivery issues

- Inventories need to be much more tightly controlled

- B to $C$ sales are much more sensitive than $B$ to $B$ movements

- $24 / 7$ operations are more demanding to manage optimally

Source: Roberts (2010)

supply chains. It does this through considering the roots of supply chain management, its effects particularly on fashion and grocery-based retailers, and then discusses current and future challenges for retail supply chain management. Further information on this transformation can be obtained from a series of books written by Fernie (1990) and Fernie and Sparks (1998, 2004, 2009). Further, the detailed operational practices required to make retail supply chains work, which are often based on sophisticated operations research techniques and models and aided by the explosion of data in retail supply chains in recent decades, are explored in Agarwal and Smith (2009).

\section{Supply Chain Management}

The roots of supply chain management are often attributed to
Peter Drucker's (1962) seminal article on 'the economy's dark continent'. At that time he was discussing distribution as one of the key areas of business in which major efficiency gains could be achieved and costs saved. Then, and through the next two decades, the supply chain was still viewed as a series of disparate functions (Langley, 1986). The real impact of supply chain management began to be felt in the 1980s (Alfalla-Luque \& Medina-López, 2009). As separate logistics functions such as warehousing, transport, and inventory management began to be integrated and considered as part of the supply chain rather than separate (and enabled by technology and information communications development), several key themes emerged:

1. A shift from a push to a pull to a demand-driven supply chain

2. Customers gaining more power in the marketing channel
3. An enhanced role for information systems to gain better control of the supply chain

4. The elimination of unnecessary inventory in the supply chain

5. A focus on core capabilities and increased outsourcing of noncore activities to specialists

To achieve maximum effectiveness of supply chains, it became clear that integration, that is, the linking together of previously separate activities within a single system, was required. Companies therefore have had to review their internal organisation to eliminate duplication and ensure that total costs can be reduced rather than allow separate functions to manage their costs in a suboptimal manner. Similarly, supply chain integration can be achieved by establishing ongoing relationships with trading partners throughout the supply chain. Increasingly such approaches include consumers 
within the concept of supply chains.

Key concepts underlying supply chain management include the value chain, resource-based theory of the firm, transaction cost economics, and network theory. The thrust of these concepts is obtaining competitive advantage through managing the supply chain more effectively (i.e., within and beyond the single firm). The aim for retailers and their supply partners is to manage this chain to create value for the customer at an acceptable cost. Managing this chain has been a key challenge for logistics and supply chain professionals, especially with the realisation that the reduction of time in the channel not only reduces costs, but also gives competitive advantage and that technology and information are key fundamentals to successful supply chain operations. This technologically informed, datadriven approach to retail supply chains has been described as the development of 'rocket science retailing' (Fisher et al., 2000). It continues to evolve and develop (Fisher, 2009).

\section{Retail Supply Chain Management in Selected Sectors}

\section{The Fashion Retail Supply Chain}

It was in fashion markets that notions of 'time-based competition' had the most significance because of the short time frames for changing styles. In addition, the prominent trend in the last decades of the twentieth century has been to source products globally, often in low-cost Pacific Rim nations, which lengthened the physical supply chain. Time has thus become a critical factor to manage, with competing tendencies of fashion and supply time. These factors combine to illustrate the trade-offs that have to be made in supply chain management and suggest an imperative to develop closer working relationships with supply chain partners, whether local or distant. At the core of such quick response and 'fast fashion' approaches is not only the concept of time (Bhardwaj \& Fairhurst, 2010), but also ideas about visibility (Barrett \& Oke, 2007) and minimising and managing disruptions in the supply chain (Oke \& Gopalakrishnan, 2009).

Christopher et al. (2004) identifies four characteristics of fashion markets:

1. Short life cycles-products are designed to represent a period in time or trend, which is getting shorter

2. High volatility-trends gain and lose popularity due to forces outside the control of fashion retailers, for example, the influence of celebrity

3. Low predictability-high volatility naturally decreases the ability to forecast sales

4. High levels of impulse purchasing-consumers place high hedonic value on fashion goods and therefore there is an instant need to purchase them

An additional operational characteristic is international sourcing, which has contributed to the success of retailers such as Zara, H\&M, New Look, Matalan, and Primark, all of whom became strong brands in the fashion market in the 1990s (Burt et al., 2006; Barnes \& Lea-Greenwood, 2006). The increased level of threats from these new companies forced existing major retailers (e.g., previous UK market leader Marks and Spencer) to focus their attention on costs and find ways to decrease consumer prices. The natural reaction to this has been for retailers to continually move production to countries with lower labour costs (Bruce et al., 2004). However there is a tension here between extensive and complex apparel supply chains with long lead times due to large geographical distances from sourcing to selling markets and the need for rapid replenishment at the right quality (Barnes \& LeaGreenwood, 2006). Fashion retailers thus far have considered the cost and price benefits of international sourcing to be of greater value than the negative impact on lead time (Fernie \& Azuma, 2004).

The significance of 'fast fashion' derives not only from its operational effects within a retailer and its supply system, but also on the changed nature of competition in the sector as a whole (Burt et al., 2006). Fast fashion is exemplified when Zara requires a different set of skills, competencies, approaches, and techniques from traditional fashion retailing. These techniques are still developing (Caro \& Gallien, 2009, Caro et al., 2010) as the demands of fast fashion, and its continuing expansion, become clearer. For traditional retailers the nature of the competition has changed, requiring all fashion and clothing retailers to 'up their game' and improve their supply chain management and performance as Figure 1 shows.

\section{The Grocery Retail Supply Chain}

Much of the research on retail logistics has focused on food/grocery retailing due to the dominance and power position of food retailers in retail sectors and economies generally. The UK is probably one of the most advanced markets in this respect. The development of supply chain management and the consequent implementation of relationship initiatives have been identified as the fourth and final stage of the evolution of grocery logistics in the UK (Fernie et al., 2000). This later relationship stage relates to a more collaborative approach to supply chain management after decades of retailer-supplier confrontation. The UK is often considered to have the most efficient grocery supply chain in the world, comprising a key contributor to the success and profit margins of its grocery retailers. Therefore, it is no surprise that retailers from other sectors and countries have attempted to copy this approach to supply chains, for example, Best Buy (2007).

This logistical transformation of UK grocery retailing has occurred in a 
short period of time (Sparks, 1998). In the first stage of evolution (pre1980) the dominant method of distribution to stores was by manufacturers that stored products at their factories or field warehouses for multiple drops to numerous small shops. As the retail multiples gained in prominence retailers invested in regional distribution centres (RDC) to consolidate deliveries from suppliers to delivery in stores. This was the first step to changing the supply of fast-moving consumer goods (FMCG) in that buying and distribution became a head office function in retailing and the logistical infrastructure created a market for third party logistics service providers.

To all intents and purposes, this change marked the removal of manufacturers and suppliers from controlling the supply chain and reinforced the switch of power to the retail end of the channel. This period of centralisation throughout the 1980 s enabled retailers to reduce lead times, minimise inventory, and give greater product availability to customers in their stores. The 1990s witnessed a consolidation of this process. In many cases inventory had been shifted only from store to RDC. By implementing just-in-time (JIT) and flow principles, retailers began to focus on their primary distribution networks (from supplier to RDC) demanding more frequent deliveries of smaller quantities. Clearly this created a problem for many suppliers in that they could not deliver full vehicle loads of product. To ensure that vehicle utilisation could be maximised, consolidation centres were created upstream of the RDC. Additionally, retailers had established supplier collection programmes to pick up products from suppliers' factories on return trips from stores.

In the first part of this century, retail networks have continued to be upgraded as efficient consumer response (ECR) initiatives were enacted and grocery retailers accommodated the increase in nonfood products through their distribution centres. Further, the greater sharing of information, especially through Internet exchanges, fostered collaborative planning, forecasting, and replenishment (CPFR) initiatives to reduce supply chain response times.

UK grocery retailers now not only control and organise the supply chain but also have taken over marketing and other responsibilities that were once the sole domain of the manufacturer, for example, product development, packaging logistics, branding, and advertising as well as distribution. The high level of retail product brand penetration has enabled them to build up store loyalty and diversify into other businesses such as banking. Control of channels and relationship building with suppliers and consumers is a way of life for such companies. This is not to say that all is perfect in such supply chains and some UK retailers have faced huge problems (e.g. Sainsbury-see Fernie \& Sparks, 2009, pp. 22-25). Disruptions to supply chains occur and are inevitably felt in product availability. Out-of-stocks remain an operational and an academic concern (Aastrup \& Kotzab, 2010; Corsten \& Gruen, 2003; Fernie \& Grant, 2008, Grant \& Fernie, 2008, 2009; Trautrims et al., 2010).

It is generally recognised that Tesco has one of the most effective and efficient grocery supply chains in the UK, if not the world. The transformation of the company has

\section{Figure 2 \\ Tesco's Supply Chain Transformation}

\begin{tabular}{|l|l|}
\hline Phase & Key issues \\
\hline $\begin{array}{l}\text { Direct to store delivery } \\
\text { (1970s) }\end{array}$ & $\begin{array}{l}\text { Supplier organised and controlled; no retailer range, } \\
\text { price, or availability control; store variability; } \\
\text { Operation Checkout almost destroyed company }\end{array}$ \\
\hline $\begin{array}{l}\text { Centralisation } \\
\text { (1980s) }\end{array}$ & $\begin{array}{l}\text { New facilities and approaches; manufacturers' and } \\
\text { suppliers' products to supply distribution centres not } \\
\text { stores; new technology and practices; outsourcing; } \\
\text { range, quality, and price control set by retailer head } \\
\text { office; distribution centres organised on product line } \\
\text { basis }\end{array}$ \\
\hline $\begin{array}{l}\text { Composite } \\
\text { (1980s and 1990s) }\end{array}$ & $\begin{array}{l}\text { Multi-temperature regional centres and vehicles; } \\
\text { productivity benefits; sharing of stock holding; increased } \\
\text { frequency of delivery to stores; better store space } \\
\text { usage; conforming superstores made supply easy; } \\
\text { quality and productivity increased and costs reduced; } \\
\text { inventory holding reduced sharply }\end{array}$ \\
\hline $\begin{array}{l}\text { Vertical collaboration and } \\
\text { lean supply chains } \\
\text { (2000s) }\end{array}$ & $\begin{array}{l}\text { Primary distribution focus; mapping value stream; flow } \\
\text { principles and lean principles introduced (simplicity, } \\
\text { transparency, and efficiency); stockless distribution } \\
\text { centres; separation by product demand; sales-based } \\
\text { ordering-driven system; supplier agreements and } \\
\text { complicity; customer focused from Clubcard data with } \\
\text { store-specific ranging; technology development and just- } \\
\text { in-time principles; continuous replenishment, flow- } \\
\text { through and network management; handling and } \\
\text { packaging logistics emphasis-shelf-ready } \\
\text { merchandising }\end{array}$ \\
\hline $\begin{array}{l}\text { Managing complexity } \\
\text { (2000s) }\end{array}$ & $\begin{array}{l}\text { Internationalisation of supply and store operations; } \\
\text { multi-format store development with new sizes, } \\
\text { approaches, and locational types; extension into } \\
\text { nonfood; Internet-based retailing and home delivery } \\
\text { based on store-based picking system; catalogue } \\
\text { retailing and single item picking and delivery from } \\
\text { centres; 24/7 operations; in-house operations extended; } \\
\text { balanced scorecard or steering wheel introduced; RFID } \\
\text { experiments; localisation of product sourcing for some } \\
\text { lines; green and sustainability initiatives-intermodal, } \\
\text { reverse logistics, collaborative transport, vehicle and } \\
\text { driver performance }\end{array}$ \\
\hline
\end{tabular}

Source: Adapted from Sparks (1986), Smith and Sparks (1993, 2004, 2009) 
been remarkable since the early 1980 s, and this has been supported and driven in part by its development of its supply chain management function. This has been the subject of considerable research (Sparks, 1986, Smith \& Sparks, 1993, 2004, 2009). Figure 2 summarises the broad phases of development and shows clearly the extensive change in approach and control that has been required. The increase in retailer control is wellmarked in the figure. The outcome of this control has been a retailerorganised supply chain operating to maximise effectiveness and efficiency in supplying consumers. As retailers such as Tesco internationalised their sourcing and store operations, so have they had to reorganise local, national, and international supply chains, not always without issues or concerns (Coe \& Hess, 2005). This retail transformation required a supply chain transformation that recognised the modern volatile and variable consumer demands and the lack of scalability of existing systems.

\section{Other Retail Sectors}

The focus of the previous examples has been the fashion and grocery sectors and some of their leading retailers. It is clear that some retailers are market leading in this regard and that excellence can be found in companies around the globe. This in turn means that the realities of retail supply chain management in smaller companies or those less organised, and in countries where the infrastructure or the channel power balance is different, require retailers to attempt to catch up with the approaches identified here. Not all companies will succeed in this and the outcomes will be different in different situations, though the search for supply chain improvement is a general theme and desire.

As an example of this and the interlinkages in retail supply chains, Figure 3 considers the supply chain for Halfords, a UK retailer of a variety of products in the automobile and bicycle market.
These are not perishable or fashion products, but are highly diverse and subject to cost and availability pressures, as with many markets. The figure shows how the same basic issues arise here in this supply chain-in a very different retail sector-as they do in fashion and grocery retail supply chains. Thus there are some generalisable tendencies as well as common current and future challenges.

\section{Current and Future Challenges}

There can be little doubt about the enormous changes in retail supply chains and their management since the 1980 s or so. Although there are inevitable debates over precisely what is meant in theory and practice by supply chain management, the operational transformation and the dominance of retailers in supply chains is clear. Nonetheless at a practical level retailers continue to have concerns about current operations and future challenges. At the Retail Week Supply Chain Summit in London in February 2010, leading UK retailers explored these concerns. Four common themes emerged:

(1) The ability to deliver end-to-end capability through partnerships. As supply chains have become more complicated (Figures 1 through 3 show this) the issues concerning integration across organisations, space, and time have become more important. Developing a customer-centric

\section{Figure 3}

\section{Supply Chain Focus in Halfords}

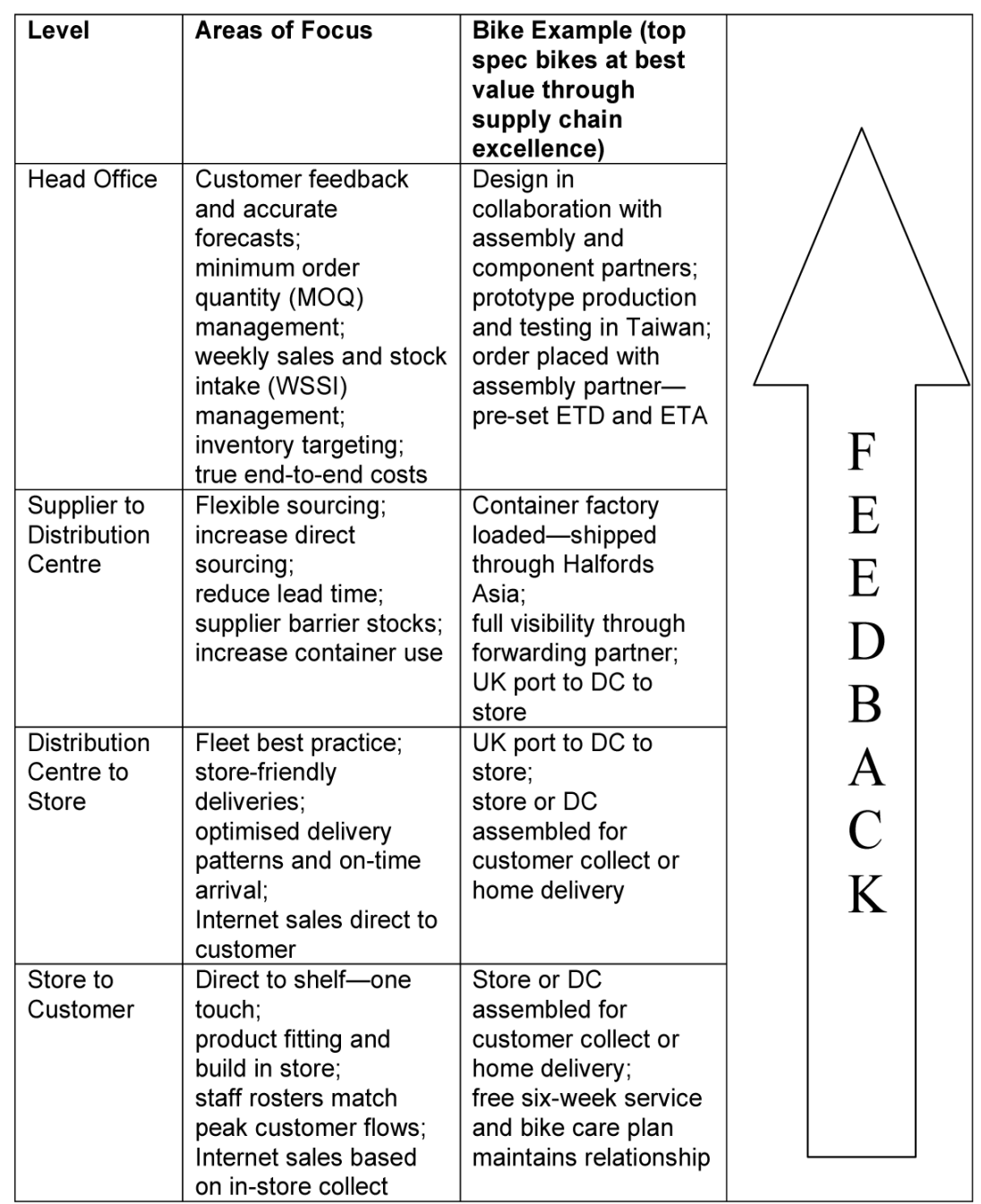

Source: Adapted from Wild (2010) 
supply chain requires that end-toend capabilities are enhanced. Thus planning, forecasting, and reacting become fundamental, though actually making this seamless flow and coordination work is complicated. Retailers are seeking increases in availability, flexibility, cost certainty, and also reductions in risk, lead times, inventories, and nonvalue-added activities.

(2) Problems with sourcing and supply of products, particularly in the clothing and fashion sectors. As has already been seen, the globalisation of sourcing brings benefits and problems to supply chains. However, it is also not a static situation because the countries and competencies as well as costs continue to alter and shift. Overlaying this is a concern for the ethics and sustainability of supply chains, particularly focused on fashion production (for example, de Brito et al., 2008). Retailers have to be ever more vigilant not only about their operations, but also about operations carried out in their name. One response to the growth of international sourcing is the use of logistics services providers or 3PLs. However a common complaint is that such providers or partners remain transaction and deal focused rather than offering global standards, solutions, and especially terms of trading.

(3) Availability. The question of product availability at acceptable cost and service levels has already been identified as a fundamentally important issue for retail supply chains. Failures in this area can have significant effects on shortterm demand and also long-term reputation. In traditional retailing, managing out-of-stocks has been seen as important. However the emergence of e-retailing has added various layers of complexity to the topic. E-retailing's emergence is well documented (e.g., Williams, 2009) and its supply chain implications have been the subject of discussion for some time, often focusing on the last mile and home delivery (e.g. Fernie \& Sparks, 2010). Additionally as retailers have expanded beyond their core sectors (e.g., Tesco's move into catalogue-based nonfood retailing) so the skills needed to operationalise the supply chain have had to expand. For example in Tesco's case they have had to learn how to pick single items for singlepoint delivery to consumers as opposed to standard primary, RDC, and store-distribution operations. Getting availability right here is a significant challenge.

(4) How to make multichannel operations work. The maturing of eretailing has led to the realisation that home delivery is but one option and retailers have to operate in a multichannel environment. There are many new issues to consider once the decision to multichannel is made. The rise of 'click and collect' or 'order to store' type systems has implications for stockholding and availability as well as delivery. Is there a common real-time stock file across all channels? If not, what dangers are there? How can demanding customers be served at acceptable cost if availability online or in-store is unknown or unclear to both customers and stores? The challenge is to be good within the channel because that drives business, but also to be great across channels because that brings efficiency gains (Xing et al., 2010). Such approaches also have to be able to cope with the problems and issues of returns and reverse flows of products and information and to deal with these very rapidly in order to avoid both under- and over-stocking (Xing \& Grant, 2006). For many retailers the Internet has changed supply chain realities, forcing them to pay ever more attention to the accuracy of stock files, good consumer information, reliability of the delivery service, competitiveness of cost structures, assortment breadth and management issues, collaboration with suppliers, and transparency for customers such as order and delivery tracking.

These issues were identified by many retailers during the Retail Week Supply Chain Summit 2010. They also suggest some common overarching themes looking forward as probable fundamental issues for retail supply chain management. Ganesan et al. (2009) provide a highly American centric view of retail supply chain challenges, perhaps reflecting a narrower viewpoint and approach than in Europe, although there is a degree of overlap. Four themes were also identified here:

(1) Efficiency: Since 2008 there has been an unprecedented downturn in the economy after a period of exceptional growth. Although not extreme globally, the negativity surrounding economies generally makes it difficult not to focus on efficiency in its broadest sense. The fluctuating price of fuel and raw material inputs have led to rises in prices of many products at a time when disposable income is being severely constrained. There are now even more reasons to be concerned with efficiency. It would seem unlikely that such cost pressures are going to diminish, and although consumer confidence and spending may return, being as efficient as possible seems like a good strategy for retail supply chain management practices. It is likely that there will be enhanced pressure to smooth flows as much as possible and to make sure that products are in their 'correct' places at all times. Modernisation of technology, equipment and systems, and staff training will be important to ensure such efficiency gains can be delivered.

(2) Transparency: A corollary of efficiency is the ability to demonstrate transparency in the supply chain for both internal and external stakeholders including consumers. If a supply chain is transparent then it is likely that it can be made more efficient. The more visible the activities are in the supply chain, then the more likely mistakes or errors will be avoided and problems and high costs can be remedied. Enhanced transparency has the potential to provide a more efficient and effective supply system and to improve availability. This transparency extends to a greater involvement of consumers through, 
for example, social media, capturing opinions, and information and ideas about supply chain actions such as packaging and reverse logistics.

Transparency has a number of dimensions but increasingly technology is providing the means to improve clarity. However there also has to be the willingness to allow transparency to occur throughout the supply chain. Radio frequency identification (RFID) has the potential to make supply chains more transparent, although at some cost, but any benefits seem to accrue at two levels: within a business and within the supply chain. If the data from RFID (and other technologies) are not shared then true improvements from the information, knowledge, and transparency will be reduced.

(3) Flexibility: There is a sense that too much focus on efficiency from a cost point of view can tie retailers into situations that are undesirable in a volatile world. When the recession hit the UK in the latter half of 2008, some retailers had supply chain problems not because they could not sell products but because they were unable to switch off their pipeline quickly enough, which was based on suddenly unrealistic forecasts of supply. Retailers are increasingly going to have to consider more flexible arrangements in all their logistical and supply chain activities. This of course requires a strong degree of partnership working.

(4) Sustainability: Probably the most fundamental change in recent years has been the recognition that supply chains and logistics are critically important in terms of green logistics and sustainability (McKinnon, 2006; McKinnon \& Edwards, 2009; McKinnon et al., 2010). The global issue of climate change has become so important that it has forced governments and businesses to consider anew practices and operations that had become entrenched. Climate change has direct effects on logistics and supply practices in many ways (Srivastava, 2007) but primarily for retailers it has meant that the ideas of green logistics and sustainable distribution have emerged as practical business concerns rather than fringe operational worries (Evans et al., 2009). At the local level the everyday intrusion of plastic bags, packaging, and trucks and air freight are visible reminders of the 'costs' of supply and distribution.

However, it is too soon to be certain about the evidence in many areas of these topics. The debates about the wisdom or otherwise of biofuels and the difficulties of lifecycle analyses are practical illustrations of the problems. At a macro level debates about the style and effect of some local production as opposed to the benefits of production in developing countries also hint at the difficulties in this area. What is certain is that all practices are being challenged by the new realities. It is less clear what the best practices are to meet the new demands and/or how retailers and supply chains transition between these states of activities. In some cases it might be possible to see small-scale changes having major channel effects (e.g., packaging reduction) but it might also be the case that radical rethinking and transformation of activities might be required (e.g., the abandonment of air freight).

There are many dimensions to sustainability. A critical aspect in the use of resources will be the need for retailers to reduce packaging and other handling inputs and to enable re-use and recycling of packaging, product, and other components. Retailers will increasingly have to demonstrate not only that they have done all they can to minimise such impacts but also that they have done all they can to maximise consumer and business opportunities in recycling and resource reduction. It needs to be accepted that some aspects will require investment by retailers but that in many instances they benefit as well, both directly in cost terms and indirectly through customer recognition of their activities. Doing the right thing can be profitable through cost reduction
(Evans et al., 2009). In some cases this may mean enhanced collaboration among retailers, for example, shared facilities, centres, vehicles and deliveries in 'neutral' white, rather than retailer branded, livery. It will make no sense to anyone to send lorries on longdistance journeys half full. It will possibly even become morally impossible. Sharing such (scarce) resources across retailers may be one way forward.

\section{Concluding Remarks}

Retailers have transformed supply chains by taking on their management and organisation. Both strategically and operationally there has been a massive change in approach. This transformation is ongoing and substantial challenges remain and can be anticipated in the future. The key challenges are to make end-to-end customer-centric supply chains visible, to aid efficiency and flexibility, to rethink existing and new activities, and to provide as sustainable a solution as possible based on sound practices and efficient operations. Retailers that succeed in this will have a major competitive advantage.

\section{References}

Aastrup, J., \& Kotzab, H. (2010). Forty years of out-of-stock research-And shelves are still empty. International Review of Retail, Distribution and Consumer Research, 20, 147-164.

Agarwal, N., \& Smith, S. A. (Eds.). (2009). Retail supply chain management. New York: Springer.

Alfalla-Luque, R., \& Medina-López, C. (2009). Supply chain management: Unheard of in the 1970s, core to today's company. Business History, 51, 202-221.

Barnes, L., \& Lea-Greenwood, G. (2006). Fast fashioning the supply chain: Shaping the research agenda. Journal of Fashion Marketing and Management, 10, 259-271. 
Barrett, M., \& Oke, A. (2007). Antecedents of supply chain visibility in retail supply chains: A resource-based theory perspective. Journal of Operations Management, 25, 1217-1233.

Best Buy. (2007). Global growth and Infrastructure. Accessed July 8, 2010, from http://library.corporate-ir.net/ library/83/831/83192/items/257835/Anal yst07_globalgrowth.pdf.

Bhardwaj, V., \& Fairhurst, A. (2010). Fast fashion-Responses to change in the fashion industry. International Review of Retail, Distribution and Consumer Research, 20, 165-173.

Bruce, M., Daly, L., \& Towers, N. (2004). Lean or agile: A solution for supply chain management in the textiles and clothing industry. International Journal of Operations \& Production Management, 23, 151-170.

Burt, S. L., Dawson, J. A., \& Larke, R. (2006). Inditex-Zara: Rewriting the rules of apparel retailing. In J. A. Dawson, R. Larke, \& M. Mukoyama (Eds.), Strategic issues in international retailing. London: Routledge.

Caro, F., \& Gallien, J. (2009). Inventory management of a fast-fashion network. Operations Research, 57, 527-540.

Caro, F., Gallien, J., Díaz, M., García, J., Corredoira, J. M., Montes, M., Ramos, J. A., \& Correa, J. (2010). Zara uses operations research to reengineer its global distribution process. Interfaces, 40, 71-84.

Christopher, M., Lowson, R., \& Peck, H. (2004). Creating agile supply chains in the fashion industry. International Journal of Retail and Distribution Management, 32, 367-376.

Coe, N. M., \& Hess, M. (2005). The internationalization of retailing: implications for supply network restructuring in East Asia and Eastern Europe. Journal of Economic Geography, $5,449-473$.

Corsten, D., \& Gruen, T. (2003). Seeking on-shelf availability-An examination of the extent, the causes and the efforts to address retail out of stocks. International Journal of Retail and Distribution Management, 31, 605-617. de Brito, M. P., Carbone, V., \& Blanquart, C. M. (2008). Towards a sustainable fashion retail supply chain in Europe: Organization and performance. International Journal of Production Economics, 114, 534-553.

Drucker, P. (1962). The economy's dark continent. Fortune, April, 265-270.

Evans, W., Jacobs, H., Sparks, L., Denny, M., Webb, K., \& Vilanova, M. (2009). Greening retail: Volume 2-Best environmental practices of leading retailers from around the world. Toronto: Ryerson, Centre for the Study of Commercial Activity.

Fernie, J. (Ed.). (1990). Retail distribution management. London: Kogan Page.

Fernie, J. (1997). Retail change and retail logistics in the United Kingdom: Past trends and future prospects. Service Industries Journal, 17, 383-396.

Fernie, J., \& Azuma, N. (2004). The changing nature of Japanese fashion. Can quick response improve supply chain efficiency? European Journal of Marketing, 38, 749-769.

Fernie, J., \& Grant, D.B. (2008). On shelf availability: The case of a UK grocery retailer. The International Journal of Logistics Management, 19, 293-308.

Fernie, J., Pfab, F., \& Marchant, C. (2000). Retail grocery logistics in the UK. International Journal of Logistics Management, 11, 83-90.

Fernie, J., \& Sparks, L. (Eds.). (1998). Logistics and retail management. London: Kogan Page.

Fernie, J., \& Sparks, L. (Eds.). (2004). Logistics and retail management (2nd ed.). London: Kogan Page.

Fernie, J., \& Sparks, L. (Eds.). (2009). Logistics and retail management: Emerging issues and challenges in the retail supply chain (3rd. ed.). London: Kogan Page.

Fernie, J., \& Sparks, L.](2010). Retail logistics in the UK: Past, present and future, International Journal of Retail and Distribution Management, 38, 11/12, 894-914.
Fisher, M. (2009). Rocket science retailing: The 2006 Philip McCord Morse Lecture. Operations Research, 57, 527540.

Fisher, M., Raman, A., \& McClelland, A. (2000). Rocket-science retailing is almost here: Are you ready? Harvard Business Review, 78(4), 115-124.

Ganesan, S., George, M., Jap, S., Palmatier, R. W., \& Weitz, B. (2009). Supply chain management and retailer performance: Emerging trends, issues and implications for research and practice. Journal of Retailing, 85, 84-94.

Grant, D. B., \& Fernie, J. (2008). Exploring out-of-stock and on-shelf availability in non-grocery, high street retailing. International Journal of Retail \& Distribution Management, 36, 661-672

Grant, D. B., \& Fernie, J. (2009). On-shelf availability and out-of-stocks in UK retailing. In P. Schnedlitz, D. Morschett, T. Rudolph, H. Schramm-Klein, \& B. Swoboda (Eds.), European Retail Research, 23, 51-76.

Langley, C. J. (1986). The evolution of the logistics concept. Journal of Business Logistics, 7, 1-13.

McKinnon, A. C. (2006). A short history of Green Logistics research in the UK. Presentation at the launch of the Green Logistics Project, Birmingham. Retrieved December 9, 2009, from www.greenlogistics.org/SiteResearch/A ShortHistory.pdf

McKinnon, A. C., Cullinane, S., Browne, M., \& Whiteing, A. (2010). Green Logistics: Improving the environmental sustainability of logistics. London: Kogan Page.

McKinnon, A. C., \& Edwards, J. (2009). The greening of retail logistics. In $\mathrm{J}$. Fernie \& L. Sparks (Eds.), Logistics \& retail management (3rd ed., pp. 253-273). London: Kogan Page.

Oke, A., \& Gopalakrishnan, M. (2009). Managing disruptions in supply chains: A case study of a retail supply chain. International Journal Production Economics, 118, 168-174.

Roberts, D. (2010). Aurora Fashions: Striking the optimum balance between cost and service. Presentation to the 
Retail Week Supply Chain Summit, London, February 9-10.

Smith, D. L. G., \& Sparks, L. (1993). The transformation of physical distribution in retailing: The example of Tesco PLC. International Review of Retail, Distribution and Consumer Research, 3, 35-64.

Smith, D. L. G., \& Sparks, L. (2004). Logistics in Tesco: Past, present and future. In J. Fernie \& L. Sparks (Eds.), Logistics and retail management (2nd ed., pp. 101-120). London: Kogan Page.

Smith, D. L. G., \& Sparks, L. (2009). Tesco's supply chain management. In J. Fernie \& L. Sparks (Eds.), Logistics and retail management (3rd ed., pp. 143-171). London: Kogan Page.

Sparks, L. (1986). The changing structure of distribution in retail companies. Transactions of the Institute of British Geographers, 11, 147-154.

Sparks, L. (1998). The retail logistics transformation. In J. Fernie \& L. Sparks (Eds.), Logistics and retail management (pp. 1-22). London: Kogan Page.

Srivastava, S. K. (2007). Green supply chain management: A state-of-the-art literature review. International Journal of Management Reviews, 9, 53-80.

Trautrims, A., Grant, D. B., Fernie, J., \& Harrison, T. (2009). Optimizing on-shelf availability for customer service and profit. Journal of Business Logistics, 30, 231-247.

Wild, D. (2010). Meeting the CEO's supply chain expectations. Presentation to the Retail Week Supply Chain Summit, London, February 9-10.

Williams, D. E. (2009). The evolution of e-tailing. International Review of Retail, Distribution and Consumer Research, 19, 219-249.

Xing, Y., \& Grant, D. B. (2006). Developing a framework for measuring physical distribution service quality of multi-channel and "pure-player" Internet retailers. International Journal of Retail and Distribution Management, 34(4/5), 278-289.
Xing, Y., Grant, D. B., McKinnon, A. C., \& Fernie, J. (2010). Physical distribution service quality in online retailing. International Journal of Physical Distribution \& Logistics Management, 40(5), 415-432.

\section{About the author}

Leigh Sparks is Professor of Retail Studies at the Institute for Retail Studies, Stirling Management School, University of Stirling, Scotland, UK. He was an undergraduate at the University of Cambridge, and completed his $\mathrm{Ph} . \mathrm{D}$ at the University of Wales. Leigh has been professor at Stirling since 1992 and a Visiting Professor at Florida State University and the University of Tennessee.

He is Editor of the leading European academic retail journal (The International Review of Retail, Distribution and Consumer Research, published by Taylor and Francis) and a number of books and many articles and reports on aspects of retailing. These include books on retailing, supply chain management and logistics, which have been translated into Arabic, Spanish, Russian, Japanese and now Chinese. He is well known for his articles, book chapters and presentations on aspects on retail logistics transformation.

Leigh is a member of the Chartered Institute of Logistics and Transport and teaches retail supply chain management to undergraduates and postgraduates at Stirling, including on the executive MBA in Retailing by distance learning, versions of which have also ran in South Africa, continental Europe and Singapore (for the Asian market).

He is an avid Welsh rugby supporter. 